\title{
Corporate and farmer objectives in the wine business: The key to success or failure
}

\author{
Francisco J Gomis Del Campo \\ David B López Lluch \\ Fernando Vidal Jiménez \\ Department of Agri-Environmental \\ Economics, Universidad Miguel \\ Hernández de Elche, Orihuela \\ Alicante, Spain
}

\begin{abstract}
This paper analyzes governance and management patterns in agricultural business. Its main objective is to evaluate business success and value creation as a result of good governance and management practices, and the changed paradigm to combine corporate and farmer objectives. We propose a theoretical framework to assess how effective governance and management can help to create value for farmers, and strengthen co-operative principles and the links between corporate and farmer objectives. The model is evaluated and tested through a survey of wine business managers, chairmen, and grape farmers in the province of Alicante in the Valencia region of Spain. According to data from the Regulatory Council, the registered area of Denominación de Origen in the province Alicante was 14.254 ha in the 2006-2007 harvest (which represented $2.23 \%$ of the Spanish total). The 3155 registered grape farmers represented $1.9 \%$ of the Spanish total. There were 48 registered companies; 16 of these were not bottling companies. There were 17 registered co-operatives. During the 2005-2006 season, 118,405 hL were marketed $(1.20 \%$ of the Spanish total). Two thirds went to the national market $(1.21 \%$ of the Spanish total); the rest was exported (1.18\% of the Spanish total).
\end{abstract}

Keywords: wine business, corporate governance, Spain, co-operative

\section{Introduction}

This paper analyzes patterns of governance and management in agricultural business. The main objective was to assess how good governance and management practices, and the change of paradigm to combine corporate and farmers' objectives, contribute to business success and value creation. In our case (wine businesses in the Alicante province of Spain) farmers can be divided into three categories:

a) A farmer who is member of a co-operative

b) A farmer who sells his/her grape production to a wine business

c) A farmer who makes wine from his/her own grapes.

These categories are quite distinct, but, a) and b) are based on the same principles: confidence and need. Farmers who make their own wine should not be considered as grape producers but wine producers. We consider a) and b) to be similar in our analysis, because almost all farmers who sell grapes sell to co-operatives as members, and because farmers who sell to other firms face similar problems as those who are members of a co-operative.

We will analyze two aspects: incentive problems (to examine how far farmers are prepared to compromise), and governance and management vs purpose in business. The common core of the many types of incentive problems is the assumption that farmers do not bear the full impact of their choices and actions. Some incentive problems are investment-related (common property/free rider, horizon, portfolio) whereas other incentive problems are decision-related (control, follow-up, influence-cost). The description of incentive problems is the result of a set of assumptions with respect to farmers' goal orientation and perceived self-interest. 
Van Dijk and Werts ${ }^{1}$ argue that farmer commitment is the organization's most important asset. They set out current criticisms of the co-operative model, and argued against these. Their arguments against co-operatives are based on agency theory. These problems are not general, but occur, only when farmers' commitment is low. Agency theory is based on the idea that the aim of every investment is to produce capital profits, but does not consider that an investment or asset's property can have the objective of ensuring commercial relations. These authors explain that co-operative rationality and its presence in so many sectors and countries is better explained through transaction cost theory, also applied to co-operatives by Staatz. ${ }^{2}$ An organization can invest in some assets just by working as a company. Thus the group needs to protect its investments against farmers' hypothetical "dishonest" behavior. Market theories do not work as expected. These authors added that farmers have the risk of being "exploited" in oligopoly markets. Thus cooperatives have the mission of reducing farmers' transaction costs, which is useful in situations where market mechanisms do not work correctly. When these market mechanisms work as expected there would be no reason to maintain cooperative structures unless their disappearance generated the same problems that existed previously.

To what extent incentive problems plague co-operative organizations depends among other things on the assumptions made about the nature of co-operative membership. For instance, the role of the member of an agricultural co-operative is based on the fact that farmers enter the co-operative in order to achieve a secure market outlet for their products. Their goal function is normally multidimensional, but the overall objective of the user is to secure market access over time, at best possible product prices. The underlying motivation for a farmer (as user) to enter a business is to reduce uncertainty related to market access, and thereby protect specific investments. Incentive problems could be the result of a mismatch between the ownership structure (co-operative) and strategic intent (clearcut investor strategy). ${ }^{3}$

Fama and Jensen ${ }^{4}$ claimed that two categories of contracts are fundamental in organizations: (1) contracts that regulate the residual rights and (2) contracts by which decision processes are designed. The former is particularly concerned with the obligations, rights and risk of the residual claimants; ie, the duties and liabilities that follow from the role as investor. Within this category, three investment-related incentive problems are commonly assumed to be of particular relevance for the co-operative form; ie. the "common property" problem, the "horizon" problem and the "portfolio" problem. The latter category (decision-related incentive problems) relates to the contracts by which decision processes are designed. Four interrelated incentive problems - the monitoring problem, the follow-up problem, the influence cost problem, and the decision problem - are briefly explained here.

Investment-related incentive problems are predominantly conceptualized according to the perspective of property right theory. Three types of investment-related incentive problems dominate in the literature" the common property problem, the horizon problem, and the portfolio problem.

The common property problem is concerned with the disparity between the farmers' contribution to the financing of investments and the distribution of benefits that result from farmers' investments. The disparity between a farmers' contribution of equity and his/her benefit from the equity is assumed to lead to free rider behavior between farmers and nonfarmers, and between existing and newly entering farmers. The common property aspects of the residual claims of a co-operative give rise to differences in the preferences of various subgroups of its farmers, based on the length of time their claims have been held. The cause of the problem is that the individual co-operative farmer has no direct or personal control over "his" respective part of the unallocated capital. The capital is held by everyone, but no one. The adversarial consequences of common property are expected to be read off both in the form of inefficiency and weak farmer commitment. ${ }^{3}$

A second incentive problem is the so-called horizon problem, which stems from the fact that residual claims of co-operatives are contingent rights to cash flows, whose validity expires when a farmer ceases to patronize the organization. Consequently, farmers are expected to become preoccupied with myopic perspectives on their co-operative membership. "Here-and-now" actions are assumed to dominate a long-term, strategic perspective on the purpose of the co-operative. A system of tradable owner shares is expected to solve the horizon problem, because farmers with a short payoff horizon could sell their ownership shares to farmers with a longer payoff horizon.

The portfolio problem occurs when farmers have diverse risk/reward profiles. As long as co-operative farmers have unequal time horizons, views on their co-operative's risk/ reward-profile will differ. According to agency theory, co-operatives should ideally have an investment portfolio that reflects the farmers' preferred trade-off between risk and reward. Vitaliano ${ }^{5}$ held that the root cause of the portfolio problem was that the restriction of residual claims to the patron group in co-operatives deprives farmers of the 
opportunity to diversify their risks by holding the claims of many organizations, either directly or through mutual stock funds and so on. Such portfolio problems can give rise to further differences in preferences among subgroups of farmers, with a general tendency for them to favor decisions with lower levels of risk.

Another group of incentive problems are linked to the decision mechanisms in co-operatives and, more generally, to agency theory. The central assumption of agency theory is that ownership and leadership or management are not only separate, but may be in conflict. More specifically, a principal-agent relationship arises when a principal contracts with an agent to perform some tasks on behalf of the principal. Barney and Hesterly ${ }^{6}$ concluded that the delegation of decision-making authority from principal to agent is particularly problematic under three conditions: when the interests of principal and agent diverge, when the principal cannot perfectly and costlessly monitor the actions of the agent, and when the principal cannot perfectly and costlessly monitor and acquire the information that is available to or possessed by the agent.

The monitoring problem stems from the fact that decision management is allocated to decision specialists who are not residual claimants. There is, therefore, a risk that agents will make decisions in such a way as to lower the value of the firm's residual claims, which gives rise to agency costs. Monitoring devices available to the traditional co-operative may be inadequate to gather sufficient information in situations where the co-operative engages in highly complex operations.

The follow-up problem is expected to occur if there are many farmers (each unable significantly to influence decision-making processes or management supervision), and individually capturing only a small fraction of potential benefits from such activities.

The influence cost problem arises when different groups of owners in the co-operative have opposing interests, each entitled to share in the distribution of benefits, and engaging in internal lobby activities to promote their own selfish interests. Finally, the decision problem relates to the situation of a large and heterogeneous membership, making it challenging for the management to decide how to weigh different farmer opinions. ${ }^{3}$

Mozas $^{7}$ analyzed the principles of farmers' economic participation in agricultural co-operatives, looking especially at exclusivity. The aim was to establish the consequences for determining whether both the performance of agricultural co-operatives, and farmers' behavior about exclusivity, constituted a useful tool for defending and ensuring the principles of equity fulfilment. Mozas ${ }^{7}$ tried to link the exclusivity or self-fulfilment of farmers with efficient management, based on empirical research among co-operatives in Jaén (Spain). The study concluded that the loyalty of farmers was a business efficiency indicator.

Nácher ${ }^{8}$ explained that human groups could be analyzed as network organizations, in which information and knowledge flow helped to ensure group survival related to the environment. Because farmers are rational beings, group survival is one way to ensure individual survival (the real objective). Nácher ${ }^{8}$ provided alternative explanations for inhibiting citizen preference for participation, and concluded by saying that democratic participation is an alternative if it produces pleasure or beauty.

An empirical approximation by $\operatorname{Mozas}^{9}$ to farmer participation in agricultural co-operatives, demonstrated why democracy breaks down in such organisations (lack of a cooperative culture, farmer unawareness of the duties of decision makers, group size and heterogeneity, lack of training). She aimed to explain participation, taking into account elements that guarantee it efficiently, and to describe farmer behavior related to participation through empirical research. She concluded that farmers are responsible for practising real democracy. Reasons for developing it depend on their willingness to do so. Farmers detect an unfair decision taking process and this leads to withdrawing democratic participation. It could be interesting to ask if the unfair decision taking process is due to democratic participation withdrawal.

The second aspect to consider are the relationships between management, governance and purpose. Davis ${ }^{10}$ stressed the importance of values, principles, and objectives in this linkage. He argued that the literature has been very strong on the identification of common co-operative values and processes, but is less sure about any general objectives that bind the whole movement in practice. As he said: "Co-operation is based on the values of community, self-help, mutual responsibility, quality, equity, service, and stewardship. They practice honesty, openness and social responsibility in all their activities". According to this interpretation, "co-operative management is conducted by men and women responsible for the stewardship of the co-operative community, values and assets. They provide leadership and policy development options for the co-operative association based upon professional training and co-operative vocation and service."

Davies and Donaldson ${ }^{11}$ have argued that much of what is "co-operative" in the broadest sense can be applied to 
general management. They affirm that general management needs some human-centred values, based on stakeholderbased management philosophies, in order to humanize work and the operation of the market place. They also argue that pluralism in the market place is a prerequisite to its effectiveness and that co-operatives are important guarantors of such pluralism. Profits are only one part of the added value created by production and distribution, and cannot act as the sole criterion for evaluating business performance. It should depend on size and type of organization. Although much emphasis is placed on profitability, co-operative management philosophy should not been excluded. Its responsibility is to ensure adequate and fair benefits to all the stakeholders, including shareholders. Co-operatives need managers who are prepared to take a broad view, avoiding any false distinction between business and social aspects, and must introduce the "seven principles for co-operative management."

Davis $^{12}$ explores the application of modern management practices to co-operatives. His central thesis is that co-operative values, principles and structures provide co-operatives with their competitive advantage, and that enterprises based on mutuality and community are better placed to apply modern management concepts. Davis ${ }^{12}$ argues that, paradoxically, however, co-operatives themselves have largely failed to utilize their human-centered values dynamically in their communications with their farmers, customers, and employees (because the movement has paid little attention to what its values mean for management).

The problems for co-operatives can be identified as a loss of focus on the provision of benefits to farmers, and the loss of control by the cardinal stakeholder group (farmers) to a variety of other stakeholders or interest groups. This study addresses the insistence in the literature that "benefit to farmers" provides the core rationale for co-operatives, and is the touchstone for defining co-operative purpose. The authors' fundamental objection to this formulation of co-operative purpose is that the idea of benefit to farmers is too general and can even be completely unrelated to co-operation. The paper argues that co-operatives are not just about individual membership and the benefits of membership in abstraction, but about the benefits of membership in association. The association's purpose is to provide market leverage and access to resources (including information) that would not otherwise be readily available to the individuals who join.

Thus management needs to establish integrated leadership of the community of labour (farmers) by being full farmers of the board. Co-operative enterprise must be managed as a whole, with no false distinction between business and social aspects. Management has the responsibility to consult, survey and research farmers' needs and the needs of the society to which they all belong. The latest market research, consultative methods, and farmer / customer oriented culture, can provide more useful information and involvement than the formal processes that underlie much of the content of co-operative democracy.

Policy provides the definition of a co-operative's strategic objectives for the organization and its key stakeholders, markets and investment priorities. Value-led policies generate in their turn programmes, whose terms of reference implement strategies for the development of products, services and markets within customer-determined quality standards and management-determined cost parameters. Organizations want their individual employees and suppliers to accept responsibility, and work to recognized standards of performance, with a constant focus on customer satisfaction. But what motivates the individual is legitimacy of purpose, the satisfaction of working towards shared values, and the social recognition by management, peers, customers and the wider community. Quality standards are driven by the customers' definition of what would be the best deal given their needs. There may be customers who are not the co-operative farmers, yet farmers are always customers. Both require quality standards determined by their respective needs and aspirations.

The first problem of evaluating co-operative performance is how to analyze this performance. Revising performance factors is useless, without establishing a framework for evaluation. Indeed undertaking any analysis without clear and measurable indicators is impossible. Two sorts of studies can be considered: first, conventional ratio analysis; ${ }^{12-23}$ second, studies looking at the benefits generated by co-operation for farmers and the environment. ${ }^{9,24-34}$ The fact that these two sets of analysis evaluate (probably) opposed objectives complicates the topic. Firstly, a company can have a strong corporate image, based on a classical business plan and farmers can feel that their needs and objectives are not sufficiently satisfied. Farmers can see corporate success as a cost. The power of the organization, the punishments they could suffer if they leave the co-operative, or the lack of alternatives are reasons to stay. Secondly, although certain firms have no growth, no retained profits and a small market share, and farmers simply feel satisfied thinking that the organization helps them reach their personal interests. Obviously, reaching success both at the corporate level and at the farmer benefit and services level requires a balance between corporate and individual objectives, because the organization and farmers 
are mutually dependent in the long term. In a recent review, Davis $^{35}$ proposed an integrated framework. Moreover, he challenged our previous assumption about farmer and corporate objectives. Both objectives have to be in agreement with co-operative values and the proposed framework for the co-operative.

There are arguments that support the idea that co-operative must be evaluated in the same way as nonco-operatives. However, financial indicators such as efficiency and profitability have to be used carefully when analyzing organizations that do not have as their sole objective maximizing farmer profits through capital growth or dividends. ${ }^{36}$ A co-operative with the objective of paying the highest price for farmers' products ${ }^{37,38}$ will have a very small profit, but could achieve a large volume of sales. Efficiency ratios can be disturbed due to non-common services and payment policies. Debt financial ratio analysis in a dynamic viewpoint offers a perspective of farmers' willingness to finance the organization, reflecting their previous behavior and their net profit expectations through their membership. ${ }^{39-41}$ Therefore accounting information analysis can lead to wrong conclusions, because different organizational objectives can distort the results.

There are also arguments that criticize these methods as useless. Co-operative success can be better evaluated looking at the services they offer to farmers, rather than the profits they make. Maybe co-operatives should include in their reports references about farmers' satisfaction evaluation. The problem is the methodology for this evaluation. Hind ${ }^{36}$ said that the number of farmers could be linked to the farmers' perceptions of the benefits they gained from the co-operative. Establishing a "farmers" benefits list" could be a reliable method if the co-operative has no restrictive policies about farmers' admission.

A way to avoid these problems would be asking farmers to give a value for their membership. Farmers could personally quantify the value of better prices, bonuses, time-saving, production improvement techniques and adequacy, safety, assurance and any other advantage that could be important for them. However they may not necessarily be willing to speak about such matters. And such quantification would not help to determine the company's value for nonfarmers, and if it has been successful counteracting the presence of middlemen in the market. It can be difficult to persuade nonfarmers that they could be in a worse situation without the co-operative.

Davis $^{35}$ proposes a model for performance management. According to the author, performance objectives in a co-operative involve the achievement of sets of task-related goals based on the business and social dimensions of the organization. These goals can be defined according to three key result areas: financial, social and environmental. This methodology can optimize all three key result areas, helping the co-operative to gain competitive advantage and to fulfil its purpose and identity. Such an analysis has four main aspects or to study: dimensions, processes, outputs and monitoring. The author introduces some possible performance indicators to indicate success or failure for each of these key result areas through a case study. These indicators are:

- Financial bottom line: profit before tax, return on equity, operating income, operating costs, cost/income ratio, average retail balances.

- Social bottom line: financial contribution, number of community programmes, number of people involved in programmes, customer and other stakeholders' opinions and perceptions.

- Environmental bottom line: waste disposal, energy use, paper and other materials consumption, levels of recycling, donations to charitable causes.

Another aspect of the model is that it stresses the fundamental importance of accurate, independent, regular and professional monitoring and assessment of co-operative performance being placed in the public domain. Furthermore, performance management relies on four essential elements: clear tasks and targets; proper resources and appropriate skills and knowledge; a sense of significance and meaning in the goals and tasks themselves; a supportive social context.

Because the co-operative is an economic organization, and because it must maintain democratic structures and decision taking processes in order to satisfy farmers and environmental expectations (in a co-operative value and purpose framework), a complex approach must be considered when evaluating performance. Three complementary approaches should be introduced: conventional management analysis (ratios); farmers' benefits and services perception analysis; and analysis of co-operative performance regarding the environment in which it operates (such as market structure, community matters of interest, environmental responsibility).

Success can be defined as the degree of fulfilment of declared objectives. A co-operative is a coalition (of different stakeholders) with several objectives. ${ }^{42}$ This mix of objectives tends toward compromise or agreement, especially because co-operatives are about the benefits of association. 
Four conditions are required to change the system of objectives in an evaluation method: declared objectives must really be pursued through action; the system of objectives must be complete, covering essential demands and areas; objectives must be operational (with a clear understanding of control procedures), and conflicting objectives must be evaluated according to their importance and priorities. The evaluation can be separated into convenient phases for study and application, based on steps or levels for reaching success. A first basic quantification of success is survival; examining co-operatives that are less than ten years old is useless. The second step is financial analysis for measuring the second step, growth. The third step is about farmers' objectives for satisfaction. Finally, the relationship of the co-operative with its local area, and how the co-operative develops its values and purpose, must be analyzed. Whether the co-operative helps to solve market maladjustments, distributes welfare in the social environment where it operates, and respects environment, must be considered. This paper aims to concentrate on the third step: farmers' objectives for satisfaction as a measure of business success. Farmers will be satisfied if their expectations became objectives, these objectives have been fulfilled, and farmers are aware of this fulfillment. Thus these objectives, their degree of fulfillment, and farmers' satisfaction, are strongly linked. The links that connect them arise from the system through which the organization sets its objectives. These links are the procedures to verify the fulfillment of agreement and the system for correcting deviations. This model can be seen graphically in Figure 1. Thus evaluation of success should cover several aspects:

1) The desire to create a business structure antedates the desire of creating a co-operative.

2) Stakeholders' perceptions about the rest of the group, especially each farmer's perceptions about the other members.

3) The minimal set of common objectives and the importance of each group's objectives for the rest of stakeholders.

4) Farmers are really involved in the organization's strategy formulation. This concentrates on:

- Clear separation between strategy and management.

- Procedure for generating new ideas.

- Formal preparation for meetings, and formal methods of obtaining information from farmers before these meetings.

- Internal communication channels.

- A clear procedure for new farmers to enter the co-operative, and for existing farmers to monitor this procedure.

5) How farmers understand management, and how their understanding affects the fulfilment of objectives, especially:
- How far work procedures, jobs, tasks, and responsibilities are clearly assigned.

- The co-operative as an organization has a clear image.

- Farmers have a clear awareness of their clients, and concerns about product quality from the consumer viewpoint.

- Managers and directors are controlled and updated.

6) Farmers declare themselves as satisfied about their membership.

The key elements of this method are the extent of farmer commitment, and adequate fulfillment of objectives. These two elements are basic to the definition of success and failure. The last two concepts should address whether "co-operatives are more or less successful" depending on farmers' expectations (the previous concept to farmers' objectives). Thus it is interesting to relate success and failure to efficiency (rational use of resources) and efficacy (objective consecution). However, co-operative objectives arise from the equilibrium between donations and the requirements of the several stakeholders. Objectives are the result of negotiation. The final agreement will show the real power of stakeholders. The limit is the survival of the organization.

\section{Data gathering, objectives, and methodology}

According to data from the Regulatory Council, the registered area of Denominación de Origen (D.O.) Alicante was 14.254 ha in the 2006-2007 campaign (which represented $2.23 \%$ of the Spanish total). There were 3155 registered grape farmers (1.9\% of the Spanish total), 21 of whom were not engaged in the wine business. There were 48 registered companies, 16 of which were not bottling companies. There were 17 registered co-operatives. In the 2005-2006 season, $118.405 \mathrm{hL}$ were marketed (1.20\% of the Spanish total). Two thirds went to the national market $(1.21 \%$ of the Spanish total); the rest is exported (1.18\% of the Spanish total).

A survey was conducted among wine co-operative managers and Chairman of the Board of Directors (BD). An exhaustive analysis was chosen because of the sample size. There were seventeen wine co-operatives in D.O. Alicante at the time of the survey. Six had no manager, and only the Chairman of the BD was in charge of management tasks, two of whom did not agree to be interviewed. Thus the survey comprised fifteen answers from the chairmen, and eleven answers from the managers. Information was obtained through personal interviews. These were conducted separately to avoid influences between chairmen and managers.

A questionnaire (see Table 1) was conducted among grape farmers. At the time of the survey, there were 3134 farmers 


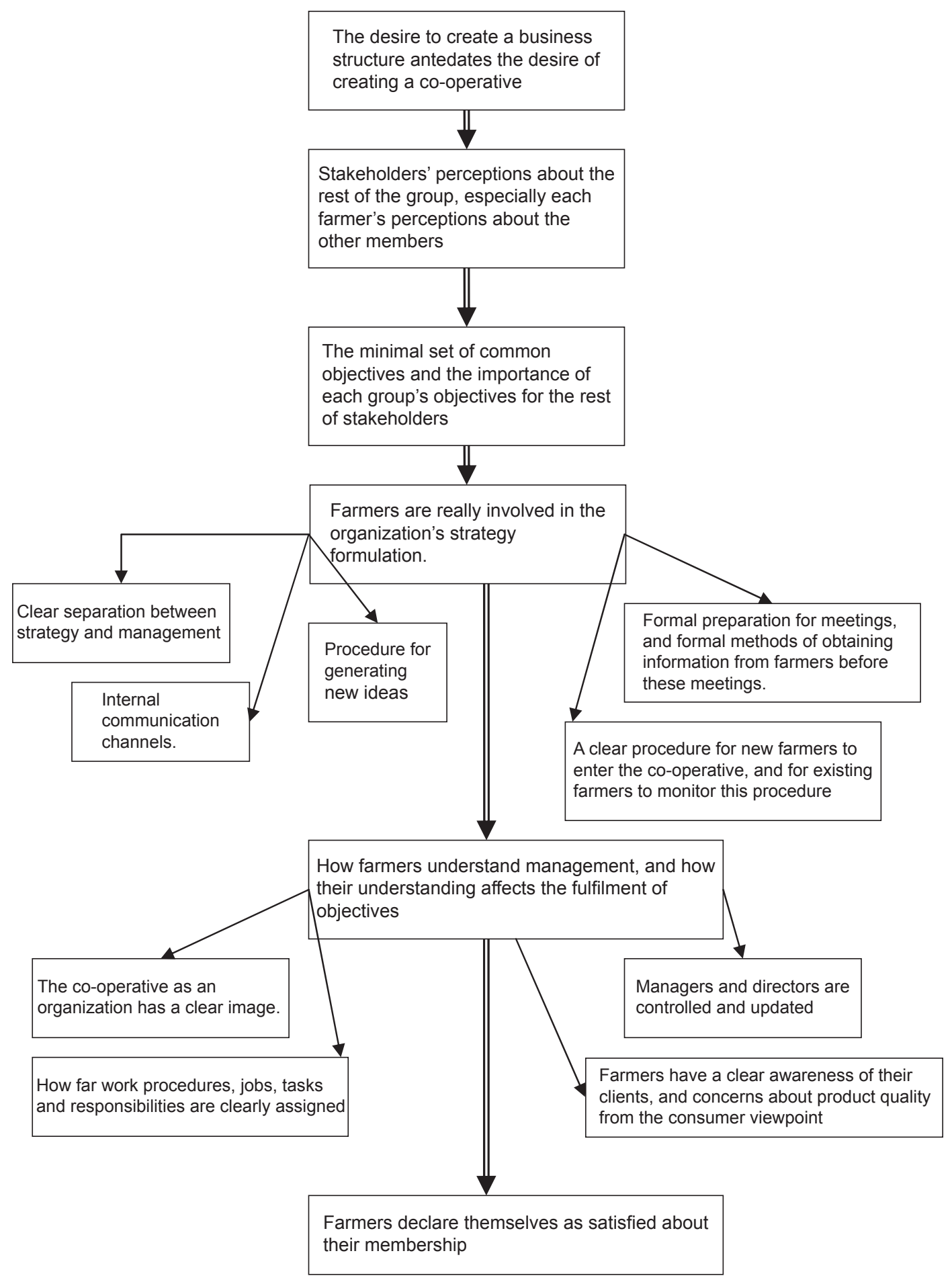

Figure I Model for success evaluation.

working in the wine co-operatives in D.O. Alicante. The chosen sample size was 300 questionnaires ( $5 \%$ sample error and $95.5 \%$ level of confidence). Two pre-tests were done. The first took into account opinions from survey design experts, and the second was based on a selected sub-sample of 30 farmers. Information was obtained through personal interviews. Respondents were casually found in the villages where these co-operatives had been established.

\section{Results}

Table 2 shows the results of the statistical analysis for dichotomy qualitative variables. Table 3 shows the results 
Table I Questionnaire

I. The desire of creating a business structure antedates the desire of creating a co-operative

$\mathrm{PI}$ a Do you think that this company would survive if it was not a co- operative?

2. Stakeholders' perception about the rest of groups, especially each farmer's perceptions about the rest of members.

$\mathrm{P} 2 \mathrm{a}$ What is your perception about the rest of members?

Evaluate, from 0 to 10 (according to their importance), the following features for members:

P2b Real implication in co-operative problem solution

P2c Faith on co-operative spirit.

P2d Concerned about the future of the co-operative

P2e Concerned about making a good product.

$\mathrm{P} 2 \mathrm{f}$ Too many requirements and demands

$\mathrm{P} 2 \mathrm{~g}$ Not concerned about day to day co-operative problems

P2h They only think about revenue

3. The minimal set of common objectives and the importance of each group's objectives for the rest of stakeholders

P3a Do you have a list of short-term objectives to work on them?

P3b And long-term?

Evaluate, from 0 to 10 (according to their importance),the following objectives for members

$\mathrm{P} 3 \mathrm{c}$ To ensure the sale of the harvest

P3d To obtain cheaper products and assessment

P3e To increase profits.

$\mathrm{P} 3 \mathrm{f}$ To participate in a co-operative organization

P3g Out of habit

P3h To get subventions

4. Farmers are really involved in the organization's strategy formulation

P4a Do you have an established way for getting involved in new ideas discussion?

P4a Do you have a way to know if members get involved in new ideas discussion process?

P4c Do you have a way to get information before meetings?

P4d Dates and meeting agenda arrive soon enough?

$\mathrm{P} 4 \mathrm{e}$ Is there a way to get information about organization changes?

P4b Do you have a way to generate, discuss, start up and evaluate new ideas?

P4f Did you talk to farmers about the reasons for becoming a member and what they expect of the co-operative?

P4g Are you aware of other members' plans regarding the co-operative?

P4c Do you have a way to get information from members before meetings?

P4e How do you ensure that information and data about organizational changes arrives to members?

P4h Regarding new members, do you have a procedure to provide them a better understanding of the organization?

5. Farmers understand management and how this affects objectives' fulfilment

P5a Would you know whom to ask if you need information about a specific aspect of the co-operative?

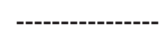

P5c Do you have a clear image in terms of design and colors?

P5b Do you think that the employees can be replaced without an excessive cost for the co-operative?

P5d Do you have clearly defined quality standards for your products and services?

P5e Would members be able to explain them?

P5f Could you tell to which markets the co-operative sells?

P5f Could you describe your targeted markets?

P5g Do you evaluate and update managers' capabilities and knowledge?

P5h Do you think that members understand how the co-operative works?

6. Farmers declare themselves as satisfied about their membership

P6a Do you think that farmers are satisfied with their membership?

When two alternatives appear, the left indicates questions to members and the right indicates questions to managers and chairmen. 
of the statistical analysis for quantitative variables. SPSS 14.0 for Windows (SPSS Inc., Chicago, IL) was used for statistical analysis. Pearson's chi-squared test, the Mann-Whitney U test, and the Kruskal-Wallis H test were performed both globally and bilaterally, in order to analyze the behavior of the three groups (farmers, managers, and chairmen). Nevertheless, it has to be said that some questions were open in their expression of how, which and why. These results are also analyzed when significant.

Results are shown through the six proposed steps for success evaluation to aid understanding of the procedure (see Figure 1).

\section{The desire to create a business structure preceded the desire \\ to create a co-operative}

This first step is analyzed through Question P1a and indicates the readiness of co-operative leaders and farmers to approach co-operation as a business structure. $86.3 \%$ of farmers declared that their co-operative would not survive if based on another kind of business structure. However, managers and chairmen ( $72.7 \%$ and $66.7 \%$, respectively) agreed that the business could survival if based on other business structures. There were statistically significant differences between the opinions of farmers, and those of chairmen and managers.

Because we wished to know why they preferred a co-operative structure, we asked them to identify the main competitive advantage of their organization. $40 \%$ of farmers identified "convenience" (to deliver the grapes and forget everything else) as the main advantage of the co-operative; $15 \%$ of farmers spoke about "the union among small farmers"; 7\% indicated that there was no advantage but a need. Answers given by managers and chairmen of the same co-operative were totally different. We also had answers like "quality", "farmer as suppliercustomer", "membership of a second tier co-operative". However, nobody spoke about market-related competitive advantages. Therefore we can say that the co-operative is the

Table 2 Analysis of dicotomic qualitative variables

\begin{tabular}{|c|c|c|c|c|c|c|c|c|c|c|c|c|c|c|c|c|}
\hline & \multirow{2}{*}{\multicolumn{2}{|c|}{ Members }} & \multirow{2}{*}{\multicolumn{2}{|c|}{ Chairmen }} & \multirow{2}{*}{\multicolumn{2}{|c|}{ Managers }} & \multirow{2}{*}{\multicolumn{2}{|c|}{$\begin{array}{l}3 \text { groups } \\
M \text { vs C vs } A \\
\chi^{2} \text { Pearson }\end{array}$}} & \multicolumn{2}{|c|}{2 groups } & \multicolumn{2}{|c|}{2 groups } & \multicolumn{2}{|c|}{$\begin{array}{l}2 \text { groups } \\
\text { M vs C }\end{array}$} & \multicolumn{2}{|c|}{$\begin{array}{l}2 \text { groups } \\
\text { M vs }(C+A)\end{array}$} \\
\hline & & & & & & & & & $\chi^{2} \mathbf{F}$ & rson & $\chi^{2} \mathrm{Pe}$ & son & $\chi^{2} \mathbf{P}$ & son & $\chi^{2} \mathbf{P}$ & son \\
\hline & $\%$ Yes & $\%$ No & $\%$ Yes & $\%$ No & $\%$ Yes & $\%$ No & $\chi^{2}$ & $\mathbf{P}$ & $\chi^{2}$ & $\mathbf{p}$ & $\chi^{2}$ & $\mathbf{p}$ & $\chi^{2}$ & $\mathbf{p}$ & $\chi^{2}$ & $\mathbf{p}$ \\
\hline $\mathrm{Pla}$ & 13.7 & 86.3 & 66.7 & 33.3 & 72.7 & 27.3 & 44.6 & $0.00 *$ & 0.1 & 0.74 & 26.1 & $0.00 *$ & 27.3 & $0.00 *$ & 44.4 & $0.00 *$ \\
\hline $\mathrm{P} 3 \mathrm{a}$ & 66.2 & 33.8 & 100.0 & 0.0 & 72.7 & 27.3 & 7.5 & $0.02 *$ & 4.6 & $0.03^{*}$ & 0.2 & 0.65 & 7.4 & $0.01 *$ & 5.3 & $0.02 *$ \\
\hline $\mathrm{P} 3 \mathrm{~b}$ & 57.4 & 42.6 & 73.3 & 26.7 & 72.7 & 27.3 & 2.4 & 0.31 & & & & & & & & \\
\hline $\mathrm{P} 4 \mathrm{a}$ & 73.5 & 26.5 & 73.7 & 26.7 & 72.7 & 27.3 & 0.0 & 0.99 & & & & & & & & \\
\hline $\mathrm{P} 4 \mathrm{~b}$ & - & - & 93.3 & 6.7 & 63.6 & 36.4 & - & - & 3.6 & 0.06 & - & - & - & - & - & - \\
\hline $\mathrm{P} 4 \mathrm{c}$ & 73.0 & 27.0 & 60.0 & 40.0 & 45.5 & 54.5 & 4.8 & 0.09 & & & & & & & & \\
\hline P4d & 94.6 & 5.4 & - & - & - & - & - & - & - & - & - & - & - & - & - & - \\
\hline $\mathrm{P} 4 \mathrm{e}$ & 85.3 & 14.7 & 86.7 & 13.3 & 81.8 & 18.2 & 0.1 & 0.94 & & & & & & & & \\
\hline P4f & 55.9 & 44.1 & 93.3 & 6.7 & 81.8 & 18.2 & 10.5 & $0.01 *$ & 0.8 & 0.36 & 7.9 & $0.01 *$ & 8.6 & $0.01 *$ & 10.2 & $0.00 *$ \\
\hline P4g & 31.9 & 68.1 & 60.0 & 40.0 & 63.6 & 36.4 & 8.9 & $0.01 *$ & 0.0 & 0.85 & 4.7 & $0.03^{*}$ & 4.9 & $0.03 *$ & 8.9 & $0.00 *$ \\
\hline $\mathrm{P} 4 \mathrm{~h}$ & - & - & 66.7 & 33.3 & 63.6 & 36.4 & - & - & 0.0 & 0.87 & - & - & - & - & - & - \\
\hline $\mathrm{P} 5 \mathrm{a}$ & 97.5 & 2.5 & 100.0 & 0.0 & 100.0 & 0.0 & 0.6 & 0.72 & & & & & & & & \\
\hline P5b & - & - & 40.0 & 60.0 & 72.7 & 27.3 & - & - & 4.7 & $0.03^{*}$ & - & - & - & - & - & - \\
\hline $\mathrm{P} 5 \mathrm{c}$ & 57.8 & 42.2 & 80.0 & 20.0 & 90.9 & 9.1 & 7.3 & $0.03 *$ & 0.6 & 0.45 & 4.7 & $0.03^{*}$ & 4.8 & $0.03 *$ & 6.9 & $0.01 *$ \\
\hline P5d & - & - & 100.0 & 0.0 & 72.7 & 27.3 & - & - & 4.6 & $0.03 *$ & - & - & - & - & - & - \\
\hline $\mathrm{P} 5 \mathrm{e}$ & - & - & 46.7 & 53.3 & 27.3 & 72.3 & - & - & 1.0 & 0.32 & - & - & - & - & - & - \\
\hline P5f & 53.9 & 46.1 & 100.0 & 0.0 & 100.0 & 0.0 & 20.3 & $0.00 *$ & n.v. & n.v. & 9.0 & $0.00 *$ & 12.1 & $0.00 *$ & 20.3 & $0.00 *$ \\
\hline P5g & 26.5 & 73.5 & 73.3 & 26.7 & 72.7 & 27.3 & 23.1 & $0.00 *$ & 0.0 & 0.97 & 10.9 & $0.00^{*}$ & 14.7 & $0.00 *$ & 23.1 & $0.00 *$ \\
\hline P5h & 53.5 & 46.5 & - & - & - & - & - & - & - & - & - & - & - & - & - & - \\
\hline P6a & 93.1 & 0.9 & 93.3 & 6.7 & 100.0 & 0.0 & 0.8 & 0.67 & & & & & & & & \\
\hline
\end{tabular}

Notes: I) F, Farmers; C, Chairmen;A, Managers. 2) “_” it indicates that this question was not made to this group. 3) "n.v.” there is no variability (identical behavior). *Statistical significance with $\mathrm{p}<0.05$. 
sole organizational option for farmers and its main advantage is "convenience."

\section{What perception do farmers, managers, and chairmen have of co-operative}

\section{farmers?}

This issue is important, in order to discover whether they share a common business project, and is essential for success (Question P2a). Perceptions of farmers, managers and chairmen about members were good: $80 \%$ of managers and chairmen agreed with this statement $72 \%$ of farmers also have a good perception of the rest of members.

It is also useful to evaluate the main impressions that farmers, managers and chairmen have about the other members of their co-operative. The feature that farmers most valued about other members was "Concerned about making a good product" (P2e). However, the feature most valued by managers and chairmen about other members was "They only think about revenue" (P2h). Both showed significant statistical differences between chairmen + managers, and farmers. This was the second feature of members according to farmers. The second feature (according to managers and chairmen) was "Worried about the future of the co-operative". Thus we can say that managers and chairmen have a favorable perception of farmers, which could be better, however.
We can also conclude that farmers consider as most important features, those related to their revenue.

\section{Is there a minimum common set of objectives?}

As there is a good general perception about members, and they share a set of features that favour economic viability, the next step was to analyze whether members, managers and presidents share a minimum common set of objectives, and to evaluate the perceptions of each group about objectives of the other groups. We looked at the existence of objectives, if they were long or short-term, and which ones they were (Questions P3a to P3h).

All the chairmen and $72.7 \%$ of managers claimed to have a list of long-term objectives. A similar percentage of both groups claimed to have a list of short-term objectives. Farmers were more concerned about short-term (66.2\%) than long-term objectives (54.6\%). However, 33.8\% of farmers claimed to have no long-term objectives at all, and $42.6 \%$ of them claimed to have no short-term objectives. There were significant statistical differences between managers + members and chairmen in long-term objectives.

The most valued objective for all the groups was "To ensure grape sale" (P3c). There were no significant differences among groups, which introduces a paradox. If this is the most important objective, there is no "common objective"

Table 3 Analysis of quantitative variables

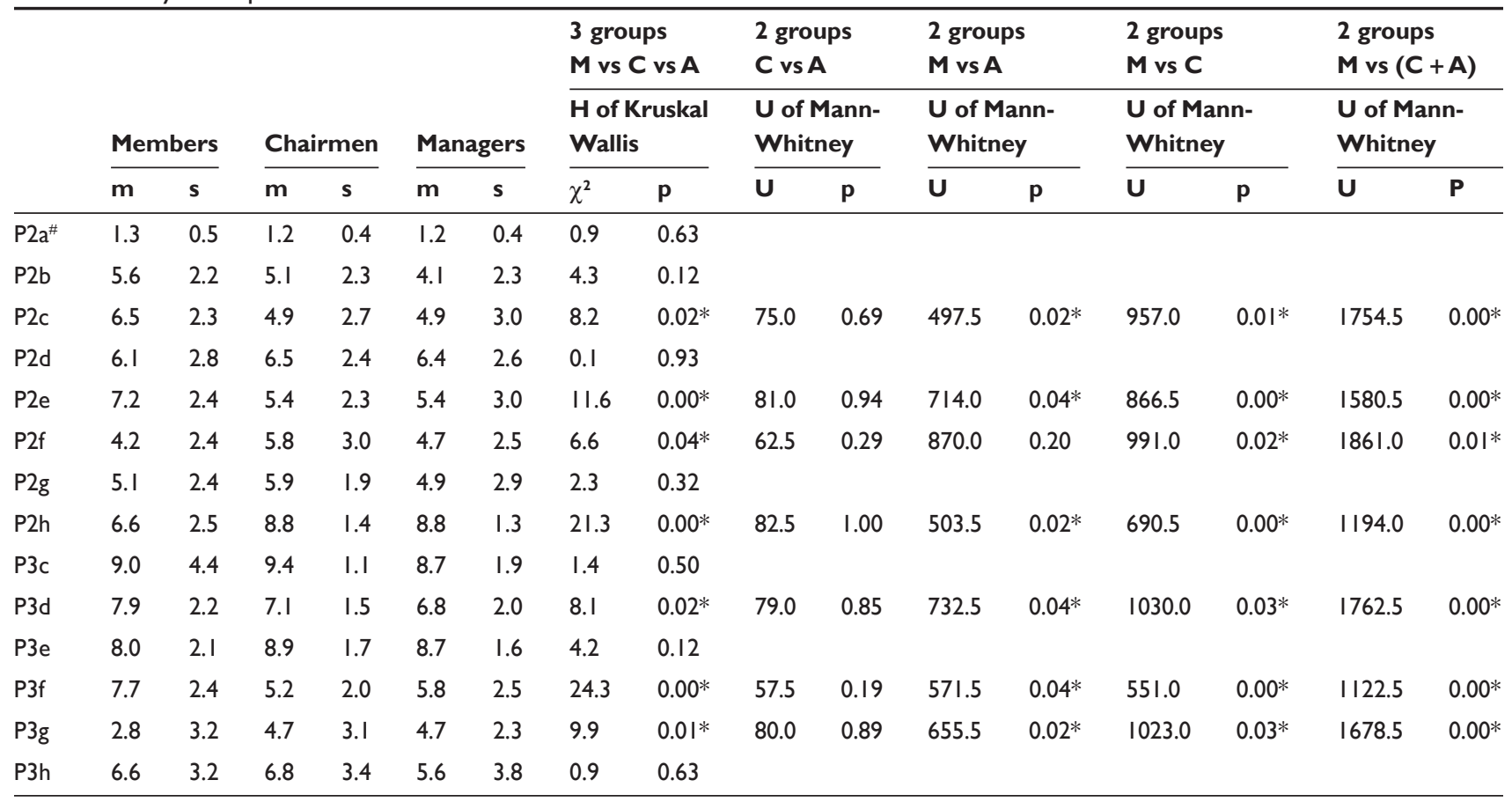

Notes: I) M, Members; C, Chairmen; m, Managers; A, average; s, standard deviation. \#Marking (Good, I; Regular, 2; Bad, 3). *Statistical significance with p < 0.05. 
because it is an individual objective: every farmer was seeking to ensure his/her harvest. On the other hand, if we consider it a common objective for the co-operative as an organization and farmers find an alternative way to sell their harvest, the co-operative could disappear. The second objective for all the groups was "To increase benefits" (P3e) with no significant differences among groups.

However, the third objective for all the groups was "To obtain cheaper products and assessment" (P3d). This objective was more valued by farmers. Significant statistical differences appeared among the three groups (farmers gave it more value than managers and chairmen).

The fourth objective for managers and farmers was "To participate in a co-operative". It was the fifth objective for chairmen. "To get subventions" was the fifth objective for managers and farmers, and was the fourth objective for chairmen. There were significant statistical differences between farmers and managers + chairmen.

No one identified "To produce wine" as a common objective. Thus the three most important objectives are related to the insurance of farmers' results, which implies that if the co-operative has to be successful (that is to say, satisfy farmers aspirations), it has to get the best economic results for farmers. However, if the most valued objective ("To ensure grape sale") is a common objective, it could lead to co-operative liquidation.

\section{Are farmers really involved in strategy formulation?}

Business objectives have a proposal, a control and a fulfillment. Thus members should be involved in the co-operative strategic process. This aspect is analyzed in several ways, which were intended to show what both groups think.

First, we wanted to know if strategy formulation and day to day management were clearly separated. We introduced an open question. Almost all the chairmen admitted that long and short-term aspects of planning were analyzed at the same time. Just one manager answered according to management theories and practices. ${ }^{43-47}$ Thus we can say that strategy formulation and day to day management are not clearly separated, which could be an indicator of their quality of management.

Then we asked the groups if members had a procedure to get involved in co-operative strategy formulation $(\mathrm{P} 4 \mathrm{a})$. Almost $75 \%$ of the three groups responded affirmatively (without significant statistical differences) and pointed to the General Assembly as the way to get involved in this process. However, it has to be said that they did not specify the procedure, or if they had a way to verify this involvement.
Generating ideas needs a procedure. Only chairmen and managers were asked about this procedure (Question P4b); $93.3 \%$ of chairmen and $63.6 \%$ of managers claimed to have a procedure for generating, discussing, implementing and evaluating new ideas. There were significant statistical differences between both groups. A disparity between the responses of managers and chairmen was also noticeable (even in the same co-operative). Evidence of the lack of a proper and clearly established procedure has to be highlighted.

Two questions were introduced to see how far members became involved in strategy formulation through the General Assembly (P4c and P4d), that is, if there was a formal way to prepare for meetings, and to obtain information from farmers before these meetings. Many members (70.3\%) said that there was a system for getting information before meetings (mainly through mail); $94.6 \%$ of members declared that the list of topics and the date of the meeting were published soon enough. Thus we can say that getting information before meetings does not seem to be a problem for farmers.

Let us analyze the reverse (that is to say, how chairmen and managers can get information from members before meetings); $60 \%$ of chairmen and $45.5 \%$ of managers answered that they had a procedure for getting this information. The most common procedure was "Talking". Answers given by the manager and the chairman of the same co-operative were never similar, however. Thus there does not seem to be a formal and established way for getting information from farmers before a meeting.

However, we looked for some informal internal communication channel to discover the extent of knowledge on reasons for becoming a member $(\mathrm{P} 4 \mathrm{f})$, and what the respondents expected from the co-operative. We also asked about knowledge of members' plans related to the co-operative (P4g). Almost all the chairmen and $81.8 \%$ of managers said that they had talked to farmers about the reasons for becoming a member, and what they expected from the co-operative; $60 \%$ of both managers and chairmen responded that they knew members' plans for the co-operative. It seems that there are some informal, internal communication channels inside these organizations.

More than half $(55.9 \%)$ of members declared that they had not talked to other farmers about their reasons for staying in the co-operative. Just a third of the members knew the plans of other members related to the organization.

There were no significant statistical differences between managers and chairmen on both questions, but there were differences between members and the other two groups. Thus we can say that although some internal informal communication 
channels exist, not all farmers have the same capability to make use of these.

The last aspect to introduce in this step is whether new members have a clear procedure to get introduced to the co-operative, and if this procedure is monitored by longer establisher member farmers. Only managers and chairmen were asked this question (p4h); 66\% of both managers and chairmen claimed to have a procedure for ensuring that new members could get a better understanding of the co-operative. A great disparity of procedures appeared to exist. The most common was to give a leaflet with the co-operative rules to new members.

When asked how they evaluated the capabilities, aptitudes and needs of new farmers, nobody referred to new members' needs. Thus no clear and established procedures to introduce new members to the co-operative seem to exist, and such introductions are not monitored by longer establisher member farmers.

We can conclude by saying that there is no clear differentiation between strategy and management, but a procedure for involving members in co-operative strategy formulation exists (through the General Assembly). Furthermore, members consider that formal communication channels operate well, although they are not able to take advantage of informal ones.

\section{Co-operative management aspects that have a clear influence on the fulfillment of objectives are well known}

If strategy has to address the declared objectives, it is important that day to day management aspects enable compliance with agreements. Thus farmers need to know how management operates in order to get a clear opinion about how far their expectations are fulfilled (their satisfaction as a member). Therefore we introduced questions P5a to P5h.

First, job places, tasks, and responsibilities have to be clearly defined (and members must be aware of such definitions). The understanding of respondents was analyzed by asking them if they knew whom to address when they needed information about a specific aspect of the organization. All managers and presidents responded affirmatively. Almost all the members also responded affirmatively. Three answers appeared when they identified whom they would address (chairman and Council of Directors 40\%; secretary 34\% and oenologist/production manager 34\%). However, only 5\% of farmers also identified the type of information needed. We cannot say that job places, tasks and responsibilities are clearly defined because although farmers think that they know these facts, their perception is wrong.

The next aspect to be discovered was the existence of clearly established working procedures (question P5b); $72.7 \%$ of managers and $40 \%$ of chairmen said that the entire workforce could be changed without important costs. Thus nothing can be said about work procedures.

Another key aspect of management is to have a clear image and presence as an organization (Question P5c); $80 \%$ of chairmen and $90.9 \%$ of managers claimed to have a defined image in terms of design and colours. However, members' opinions were not as clear because only $57.8 \%$ of them declared that their organization had a clearly defined image. There were significant statistical differences between members and managers + chairmen.

The fourth managerial aspect to analyze is farmers' concern about quality from the viewpoint of the consumer. Chairmen and managers were asked about these issues (Questions P5d and P5f). All the chairmen and $66 \%$ of managers claimed to have clearly defined quality standards for their products and services, but only $10 \%$ of co-operatives referred to their own standards. Furthermore, $46.7 \%$ of chairmen and $27.3 \%$ of managers said that members could explain these standards, which does not indicate much confidence in the training and capabilities of farmers to produce grapes according to co-operative standards. Respondents were also asked about how they evaluated the standard fulfilment. The most common answer was "Through the oenologist." Thus chairmen and managers do not seem to have a clear understanding about quality from the viewpoint of consumers.

Members must have a clear understanding of customer requirements. This aspect can help us to understand farmers' interests in co-operative management (Question P5f). Such knowledge is an indicator of performance in the role as owner (and not just as supplier). 46.1\% of farmers declared that they did not know the targeted markets of the co-operative. This result indicates how farmers (members) behave more as suppliers (grape producers) than owners (wine producers).

On the other hand, chairmen and managers declared that they knew these targets. However, their answers were ambiguous and, in some co-operatives, contradictory.

None of the members who declared that they knew the targeted markets of the co-operative could define these in terms of potential consumers. They stressed the importance of middlemen and distributors. Many spoke about bulk markets as targeted markets. Thus it cannot be said that farmers have a clear understanding of clients, and understand a very important part of co-operative management, that is to say, marketing. 
Members must monitor and update their managers in order to check whether these managers performed well (Question P5g); 26.5\% of members said that the co-operative had some system to ensure this monitoring; $75 \%$ of chairmen and managers agreed that they had such a monitoring system. There were significant statistical differences among groups. The fact is that the answers given about how they do this monitoring and updating do not reveal a standardized procedure with objective indicators. Furthermore, the Council of Directors and the General Assembly are in charge of checking that the decisions are effectively implemented (instead of area managers). Thus farmers (members) admitted that they are not monitoring the tasks that managers and chairmen are supposed to do.

Finally, we asked members whether they thought they understood how the co-operative worked (Question P5h). Just $53 \%$ of respondents agreed, which confirms the evidence of general ignorance of members about the management of their co-operative. This lack of knowledge could influence the fulfillment of their objectives and their satisfaction.

\section{Do farmers feel satisfied with their membership?}

The questionnaire finished by asking farmers if they were satisfied as members (Question P6a). A majority (93.1\%) of farmers declared that they were satisfied with their membership. However, we can separate two groups of farmers: those who felt satisfied because their sole aim was to sell the product (31\%) and those who felt satisfied because the co-operative performed well and its management was positive (30\%).

\section{Conclusions}

This article emphasizes the role of farmers as the most important for co-operative success. Indeed the co-operative will be successful if farmers feel satisfied with their membership. However, as the study showed, objectives are the result of negotiation between farmers, Board of Directors and the cooperative as an organization. The conflict between farmers and the BD could result in difficulty reaching the objectives of the organization (which are common to farmers and BD). However, as indicated, "benefit to farmers" is too general and can actually be completely unrelated to the notion of co-operation. Co-operatives are about the benefits of membership in association. The association's purpose is to provide market leverage and access to resources (including information), which would not otherwise be readily available to the individuals who join. The purpose of social justice, through market leverage and the common strategy of community building, sets the final measurement of success. It is not about delivering this or that benefit but about mobilizing economic and social resources to deliver economic and social justice, and destroy dependency in the global market. The achievement of co-operative value and purpose allows the organization to become an added value generator for all the stakeholders. Stakeholder objectives and organizational objectives are not opposed but complementary. Problems could arise if short-term objectives (farmers' needs satisfaction) are more important than long-term corporate objectives.

The case of the wine businesses of D.O. Alicante has shown how farmers that belong to co-operatives as members do not understand how these businesses work. This fact hampers the possibilities of developing business strategy.

It is possible to conclude that members (farmers) do not consider themselves as wine producers but grape producers (they declare it in the objectives that they specified). The business (co-operative) as an opportunity to diversify and broaden their activities is not important for them (which is revealed by their answers on their knowledge of co-operative markets or quality standards).

Thus, as demonstrated, there is a conflict between corporate objectives (to produce quality wine) and farmers' (members) objectives in these wine businesses. If the most important objective for farmers is to ensure the sale of the harvest, there is no "common objective" because that is an individual objective: every farmer seeks to ensure his/her harvest. On the other hand, if we consider the sale of the harvest a common objective for the co-operative as an organization, and farmers find an alternative way to sell their harvest, the co-operative could disappear.

\section{Disclosure}

The authors report no conflicts of interest in this work.

\section{References}

1. van Dijk G, Werts J. The Co-operative's most precious asset: Farmer involvement. Seizing Control: the International Market Power of Co-operatives. Rochester MI: Lone Oak Press; 1996. p. 102-122.

2. Staatz JM. Farmer action to take collective action via co-operatives: A transaction cost approach. In: Co-operative Theory: New Approaches. Washington, DC: USDA. 1987.

3. Borgen $\mathrm{S}$. Rethinking incentive problems in co-operative organizations. J Socio-Economics. 2004;33:383-393.

4. Fama EF, Jensen MC. Separation of ownership and control. J Law Econ. 1983;XXVI:301-325.

5. Vitaliano P. Cooperative enterprise: an alternative conceptual basis for analyzing a complex institution. Am J Agr Econ. 1983;65:1078-1083.

6. Barney JB, Hesterly W. Organizational economics: understanding the relationships between organizations and economic analysis. In: Clegg S, Hardy C, Nord WR, editors. Handbook of Organization Studies. London: Sage; 1996. 
7. Mozas A. La fidelidad del socio como indicador de la eficiencia empresarial en la sociedad cooperativa: una aproximación empírica. Valencia: CIRIEC-España, revista de economía pública, social y cooperativa. $n^{\circ} 34 ; 2000$. p. 23-50.

8. Nácher J. Teoría de la participación. Sugerencias analíticas. Valencia: CIRIEC-España, revista de economía pública, social y cooperativa. $n^{\circ} 40 ; 2002$. p. 9-42.

9. Mozas A. La participación de los socios en las cooperativas agrarias una aproximación empírica. Valencia: CIRIEC-España, revista de economía pública, social y cooperativa. no 40;2002. p. 165-193.

10. Davis P. Co-operative management and co-operative purpose: values, principles, and objectives for co-operatives into the 21 st century. Discussion Papers in Management Studies. Faculty of Social Sciences. Management Centre. Leceister: University of Leicester; 1995.

11. Davis P, Donaldson J. Co-operative Management. A Philosophy for Business. Cheltenham: New Harmony Press; 1998.

12. Davis P. Managing the Co-operative Difference. Geneva: International Labour Organization; 1999.

13. Caballer V, Juliá JF, Segura B. Estructura financiera de las cooperativas hortofruticolas valencianas. I Congrés d'Economía Valenciana. Valencia: Generalitat Valenciana; 1984.

14. Segura B, López F. El estado de origen y aplicación de fondos y el análisis financiero en cooperativas. Agricultura y Cooperación. 1985;25:19-20.

15. Romero C, Domingo J. Las empresas cooperativas agrarias: Una perspectiva económica. Madrid: Mundi-Prensa; 1987.

16. Segura B, Server R. Situación económico-financiera de las Organizaciones de productores de frutas y hortalizas (OPFH) en la Comunidad Valenciana. Investigación Agraria. 1990;5:19-37.

17. Segura B, Oltra MJ. Eficiencia en la gestión de las cooperativas agrarias de comercialización. Investigación Agraria Economía. 1995;10:217-232.

18. Segura B, Vidal F, Del Campo FJ, Martínez-Carrasco L. El sistema de dirección de las cooperativas de comercialización hortofrutícola de la Comunidad Valenciana. Murcia: Actas de Horticultura. SECH. $\mathrm{N}^{\circ} 27$; 1998. p. 325-331.

19. Sabaté P. La estructura financiera de las cooperativas agrarias. Las cooperativas comercializadoras de fruta de la provincia de Lleida. Investigación Agraria. 1999;14:495-513.

20. Vidal F, Segura B, Del Campo FJ. Rentabilidad Económica de las Cooperativas de Comercialización Hortofrutícola de la Comunidad Valenciana. Osuna: I Congreso sobre Cooperativismo Español; 2000.

21. Vidal F, Segura B, Del Campo FJ. Caracterización empresarial del cooperativismo de comercialización hortofrutícola de la Comunidad Valenciana: un análisis provincial. Valencia: CIRIEC-España, revista de economía pública, social y cooperativa. No 34;2000. p. 71-94.

22. Domingo J. Ratios para el análisis de rentabilidad de las cooperativas agrarias andaluzas. Valencia: CIRIEC-España, revista de economía pública, social y cooperativa, no 38;2001. p. 171-186.

23. Montegut Y, Sabaté P, Clop MM. Análisis económico - financiero de las cooperatives agrarias productoras de aceite de oliva de la "D.O. Garrigues" (Lleida, España). Investigación Agraria. 2002;17:423-440.

24. Caballer V. Aspectos económicos de las altas y bajas de los socios en las cooperativas agrarias. Economía Política. 1982;90:201-217.

25. Ballestero E. Teoría económica de las cooperativas. Madrid: Alianza Universidad; 1983.

26. Caballer V. Reflexiones en torno al cooperativismo (La situación española actual). Valencia: CIRIEC-España, revista de economía pública, social y cooperativa, no $5 ; 1988$. p. 165-178.

27. Ballestero E. Economía Social y empresas cooperativas. Madrid: Alianza Universidad; 1990.
28. Del Pino J. El cooperativismo agrario como factor de integración de la agricultura de Andalucía en la Unión Europea. Valencia: CIRIECEspaña, revista de economía pública, social y cooperativa. $n^{\circ} 18 ; 1995$. p. 83-108.

29. Montero A. Funciones económicas de las cooperativas agrarias. Jornadas de Integración Cooperativa. Mérida: UNEXCA; 1995.

30. Bel P. Las cooperativas agrarias en España. Análisis de los flujos financieros y de la concentración empresarial. Valencia: CIRIECEspaña; 1997.

31. Del Pino J. La satisfacción y la alineación en los socios de las empresas cooperativas." Valencia: CIRIEC-España, revista de economía pública, social y cooperativa. $n^{\circ} 33 ; 1999$. p. 141-154.

32. Juliá JF, Del Campo FJ. Relationship between cooperatives and their farmers: procedures, principles and practices in Spain. The World of Cooperative Enterprise. Oxford: Plunkett Foundation; 1999. p. 87-94.

33. Bel P, Buendía I, Rodrigo M. Las cooperativas y su relación con los fondos estructurales de la Unión Europea: un estudio de la politica de desarrollo rural. Valencia: CIRIEC-España, revista de economía pública, social y co-operative, $\mathrm{n}^{\circ}$ 35;2000. p. 101-124.

34. García AM, Oreja JR, González E. Las relaciones verticales y el poder de negociación de los agricultores integrados en forma de cooperativa frente a los individuales. Valencia: CIRIEC-España, revista de economía pública, social y co-operativa. n 41;2002. p. 111-137.

35. Davis P. Human Resource Management in Co-operatives. Geneva: International Labour Organization; 2004.

36. Hind A. Assessment of business performance. The World of Cooperative Enterprise. Oxford: Plunkett Foundation; 1998. p. 9-18.

37. Caballer V, Juliá JF, Segura B. Economía de la Co-operativa Hortofrutícola. Madrid: M.A.P.A. Dirección General de la Producción Agraria Ed; 1985

38. Juliá JF. Algunos aspectos de la liquidación de cosechas a los socios en cooperativas hortofrutícolas. Madrid: Anales del INIA. Serie Economía y Sociología Agrarias, nº 9;1985. p. 115-137.

39. Romero C. Análisis económico de los mecanismos de financiación de socios y de autofinanciación de las empresas co-operativas españolas". Madrid: Anales del INIA. Serie económica y sociología agraria, no 5;1980. p. 73-93.

40. Domingo J. Las necesidades de financiación de las co-operativas en la perspectiva del Mercado Único. Valencia: CIRIEC-España, revista de economía pública, social y co-operativa, nº 13;1993. p. 101-122.

41. García-Gutiérrez C. El coste de capital de la sociedad co-operativa. Valencia: CIRIEC-España, revista de economía pública, social y cooperativa. $n^{\circ} 14 ; 1993$. p. 171-197.

42. Caballer V. Un modelo explicativo de la estabilidad social en empresas cooperativas con actividad cooperativizada múltiple. Valencia: CIRIEC-España, revista de economía pública, social y cooperativa, $\mathrm{n}^{\circ} 8 ; 1990$. p. 143-165.

43. Piercy P. Market-Led Strategic Change. 1st edition. London: Butterworth-Heinemann; 1992.

44. Wilson RMS, Gilligan C, Pearson DJ. Strategic Marketing Management: Planning, Implementation and Control. 1st edition. London: Butterworth-Heinemann; 1992.

45. Dobson P, Starkey K. The Strategic Management Blueprint. 1st edition. London: Blackwell Business; 1993.

46. Johnson G, Scholes K. Exploring Corporate Strategy. London: Prentice Hall International; 1993.

47. Ansoff HI. La Dirección y su actitud ante el entorno. 1st edition. Bilbao: Ediciones Deusto; 1997. 